\title{
Cytotaxonomic diagnosis of Trichomycterus diabolus (Teleostei: Trichomycteridae) with comments about its evolutionary relationships with co-generic species
}

\author{
Rodrigo A. Torres*, Claudio Oliveira** and Fausto Foresti**
}

The karyotype and the Ag-NOR location of a sample of Trichomycterus diabolus collected in the córrego Hortelã (Botucatu, São Paulo, Brazil) are described. The species exhibited 2n=56 chromosomes (42 metacentrics, 12 submetacentrics and 2 subtelocentrics) and the nucleolus organizing region located near to the centromere on the long arm of the largest metacentric pair. The presence of $2 \mathrm{n}=56$ chromosomes in T. diabolus is an interesting characteristic since until now all cis-Andean species karyotyped presented $2 \mathrm{n}=54$ chromosomes while almost all trans-Andean species presented different diploid numbers. The possible origin of this unexpected karyotypic form is discussed.

São descritos o cariótipo e a localização das regiões organizadoras de nucléolo (Ag-NOR) de uma amostra de Trichomycterus diabolus, coletada no córrego Hortelã (Botucatu, São Paulo, Brasil). A espécie apresentou 2n=56 cromossomos (42 metacêntricos, 12 submetacêntricos e 2 subtelocêntricos) e as regiões organizadoras de nucléolo localizadas próximas ao centrômero, no braço longo do maior par metacêntrico. A ocorrência de 2n=56 cromossomos em Trichomycterus diabolus é uma característica interessante, uma vez que, até o momento, todas as espécies cis-Andinas cariotipadas apresentaram $2 \mathrm{n}=54$ cromossomos, enquanto que quase todas as espécies trans-Andinas apresentaram números diplóides diferentes. É discutida a possível origem desta inesperada estrutura cariotípica.

Keywords: Trichomycterinae, karyotype, chromosome evolution, fish cytogenetic

\section{Introduction}

The family Trichomycteridae, with about 200 species described, is one of the most diverse Neotropical catfishes group (de Pinna \& Wosiacki, 2003). The genus Trichomycterus has about 120 species, distributed in Central and South America from Costa Rica to north Argentina, in both sides of Andes (Wosiacki \& Garavello, 2004). The genus is not monophyletic and has many taxonomic and systematic problems (Wosiacki, 2002; de Pinna \& Wosiacki, 2003).

Until now cytogenetic studies were carried out with about 18 species of the family Trichomycteridae (reviewed by Sato et al., 2004). The diploid numbers range from $2 \mathrm{n}=52$ in Hatcheria macraei to $2 \mathrm{n}=64$ in Vandellia cirrhosa, but 11 species (ten cisAndean species) have $2 \mathrm{n}=54$ chromosomes (Sato et al., 2004). Aiming to extend the knowledge about the karyotype constitution of this fish group, the present paper describe the karyotype of a recent discovered species, Trichomycterus diabolus, that occur in tributaries of the Paranapanema river. The results are compared with those available for other species of the family.

\section{Material and Methods}

The species Trichomycterus diabolus (Fig. 1) was recently found in tributaries of the rio Paranapanema (Bockmann et al., 2004). In the present study six specimens ( 3 males and 3 females) of $T$. diabolus were collected in the córrego Hortelã $\left(22^{\circ} 55^{\prime} \mathrm{S}\right.$ $48^{\circ} 30^{\prime} \mathrm{W}$ - a small tributary of the rio Pardo, an important component of the rio Paranapanema basin), Botucatu, São Paulo, Brazil, and karyotyped. The specimens analyzed were deposited in the collection of Laboratório de Biologia e Genética de Peixes, Departamento de Morfologia, UNESP, Botucatu (LBP 143).

\footnotetext{
*Laboratório de Genômica Evolutiva e Ambiental, Departamento de Zoologia, Universidade Federal do Paraná, Centro Politécnico, Setor de Ciências Biológicas, Jardim das Américas, POBox 19020, 81531-990 Curitiba, PR, Brazil. e-mail: ratorres@ufpr.br

**Laboratório de Biologia e Genética de Peixes, Departamento de Morfologia, UNESP, Botucatu, SP, Brazil
} 


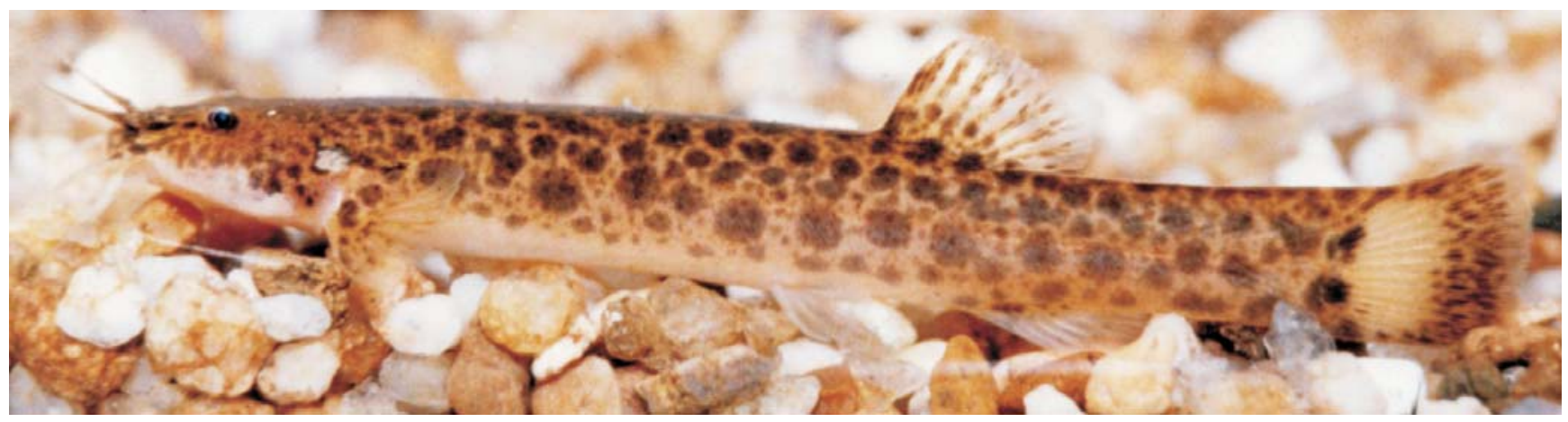

Fig. 1. A specimen of Trichomycterus diabolus with $110 \mathrm{~mm}$ in total length. Photo by C. Oliveira.

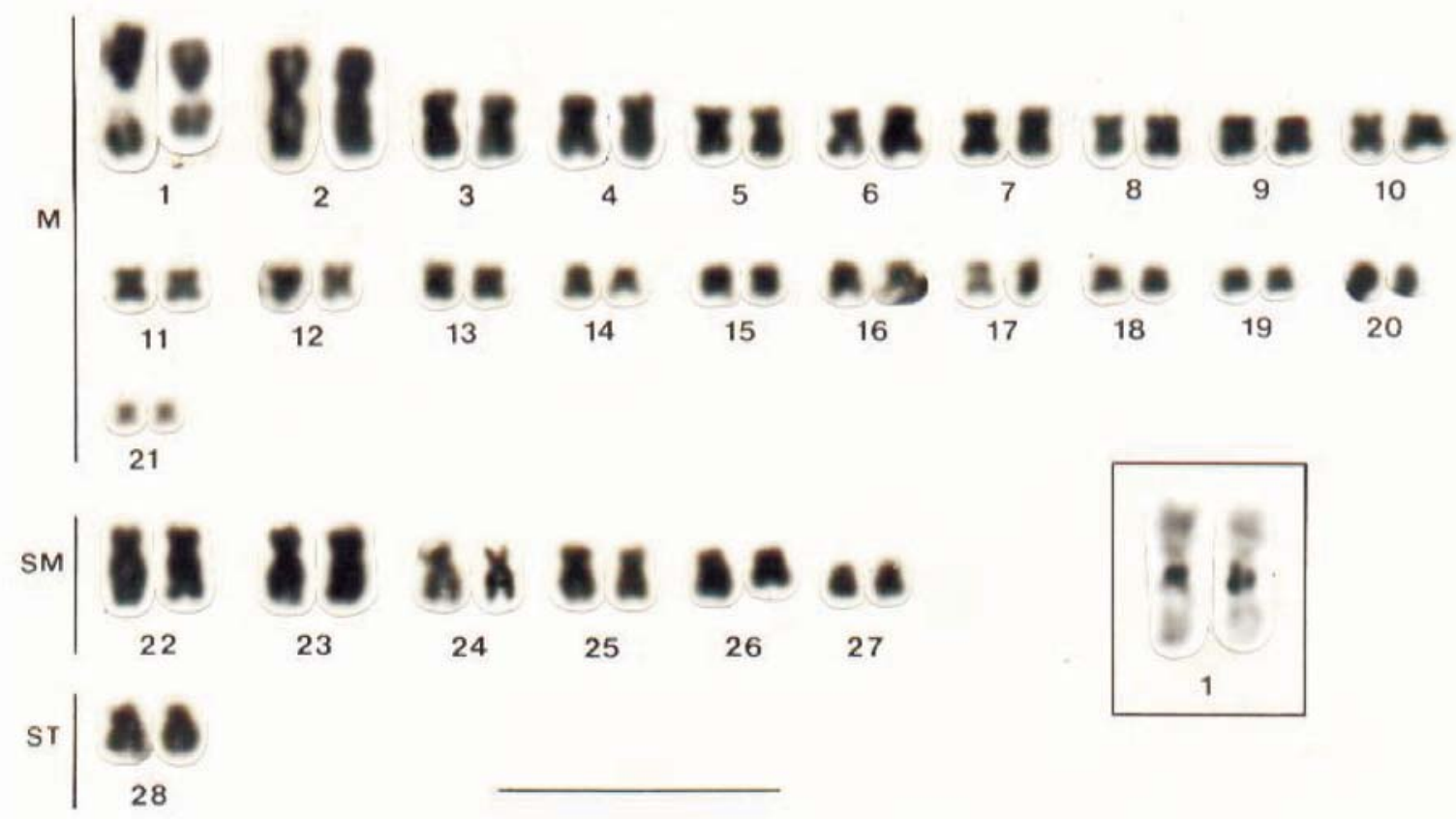

Fig. 2. Karyotypic macrostructure of Trichomycterus diabolus. In detail the NOR-bearing chromosome pair after silver staining. $\mathrm{M}=$ metacentrics; $\mathrm{SM}=$ submetacentrics; $\mathrm{ST}=$ subtelocentrics chromosomes. $\mathrm{Bar}=10 \mu \mathrm{m}$.

Chromosome preparations and staining techniques were conducted according to Foresti et al. (1993). Chromosome morphology was determined on the basis of arm ratio, as proposed by Levan et al. (1964), and chromosomes were classified as metacentrics (M), submetacentrics (SM) and subtelocentrics (ST).

\section{Results and Discussion}

The chromosomal analyses performed in $T$. diabolus revealed the occurrence of $2 n=56$ chromosomes and the karyotypic formula: $42 \mathrm{M}+12 \mathrm{SM}+2 \mathrm{ST}$ (Figure 2). The Ag-NOR is located near to the centromere region on the long arm of the first metacentric chromosome pair (Fig. 2).

The presence of $2 \mathrm{n}=56$ chromosomes in $T$. diabolus is an interesting feature since until now, only $T$. areolatus from Chile (Arratia \& Veloso, 1980) was known as having the same diploid number. However, the absence of additional information about the karyotype of $T$. areolatus makes difficult a comparative analysis with $T$. diabolus. On the other hand, the karyotype of $T$. diabolus has two marked characteristics: (1) the two largest M pairs have similar sizes and are considerably larger than the other M pairs; and (2) the Ag-NOR is interstitially located in a large M pair. These characteristics were already found in some other Trichomycterus species, as T. paolence (Torres et al., 1998), T. davisi, T. stawiarski and Trichomycterus sp. (Borin \& Martins-Santos, 1999), and Trichomycterus sp. aff. T. itatiayae (Sato et al., 2004) suggesting that T. diabolus may be related with these species. Indeed, the karyotype of $T$. diabolus only differ from that of Trichomycterus sp. aff. T. itatiayae (Sato et al., 2004) by the presence of an additional SM pair.

T. diabolus is morphologically similar to T. castroi, which 
is distributed in small streams of the rio Iguaçu basin (Bockmann et al., 2004). Phylogenetic studies conducted by Wosiacki (2002), using morphological data, showed that $T$. davisi, T. castroi, T. stawiarski and two new species of Trichomycterus are, in this order, the most derived clades of Trichomycterinae, but are not related to T. areolatus, which is a basal clade. In addition, Sato (2003) obtained similar results using molecular data, showing that $T$. diabolus and $T$. davisi belong to the most derived monophyletic group of Trichomycteridae, reinforcing that these species are not related to T. areolatus.

Considering the karyotypic and phylogenetic data, it is possible to suggest that the karyotype of $T$. diabolus was originated from an ancestral with $2 \mathrm{n}=54$ chromosomes. However, the available data are not informative about the origin of the additional SM pair found in this species since there is no evidence of chromosome rearrangements such as centric fissions. It is interesting to note that $T$. davisi, a species related to $T$. diabolus, showed an additional supernumerary microchromosome (Borin \& Martins-Santos, 1999).

Caramaschi (1986), in an wide ecological and ichthyofaunistic study, recognized five morphotypes of Trichomycterus in the Cuesta of Botucatu. These morphotypes are easily distinguishable by their particular color patterns, presence or absence of ventral fins, position of anal and dorsal fins, eye size and shape of the caudal fin boundary. In three of those morphotypes it was found $2 n=54$ chromosomes, although differing by particular karyotypic features (Torres et al., 1998). The data obtained in the present study show that the fourth morphotype, actually identified as T. diabolus, also has particular karyotypic characteristics that distinguish it from the previous three forms, being the presence of a different diploid number $(2 n=56)$ the most striking feature.

Until now, all cis-Andean species of Trichomycterus karyotyped presented $2 \mathrm{n}=54$ chromosomes while all the transAndean species presented different diploid numbers (Sato $e t$ $a l ., 2004)$. Thus, the presence of $2 \mathrm{n}=56$ chromosomes in $T$. diabolus is an exception for that general rule. Considering that $T$. diabolus is not related with any trans-Andean Trichomycterus species, the presence of $2 \mathrm{n}=56$ chromosomes in this species may indicate that changes in chromosome number among the cis-Andean species may not be so rare as previously supposed (Sato et al., 2004). Further chromosome analysis of additional Trichomycterus species will permit to better understand the extension of chromosome rearrangements in this genus.

\section{Ackowledgements}

The authors are very grateful to Renato Devidé for technical assistance, to Mário C.C. de Pinna for specimens identification and to Marcio Pie for his contribution in the manuscript. Grants supporting this study were provided by CNPq, CAPES and FAPESP.

\section{Literature Cited}

Arratia, G. \& A. Veloso. 1980. Cariótipo de peces Trichomycteridos (Siluriformes). Archivos de Biología y Medicina Experimentales, 13(1):137.

Bockmann, F. A., L. Casatti \& M. C. C. de Pinna. 2004. A new species of trichomycterid catfish from the Rio Paranapanema basin, southeastern Brazil (Teleostei: Siluriformes), with comments on the phylogeny of the family. Ichthyological Exploration of Freshwaters, 15(3): 225-242.

Borin, L. A. \& I. C. Martins-Santos. 1999. Karyotype characterization of three species of the genus Trichomycterus (Teleostei, Siluriformes) from Iguaçu river basin. Genetica, 106: 215-221.

Caramaschi, E. P. 1986. Distribuição da ictiofauna de riacho das bacias do Tietê e Paranapanema, junto ao divisor de águas (Botucatu, SP). Unpublished Doctoral Thesis. Departamento de Ciências BIológicas, Universidade Federal de São Carlos. 245p.

Foresti, F., C. Oliveira \& L. F. Almeida-Toledo. 1993. A method for chromosome preparations from large specimens of fishes using in vitro short treatment with colchicine. Experientia, 49: 810-813.

Howell, W. M \& D. A. Black. 1980. Controlled silver staining of nucleolus organizer regions with a protective colloidal developer: a 1-step method. Experientia, 36: 1014-1015.

Levan, A., K. Fredga, \& A. A. Sandberg. 1964. Nomenclature for centromeric position on chromosomes. Hereditas, 52: 201-220.

Pinna, M. C. C. de \& W. Wosiacki. 2003. Family Trichomycteridae. Pp. 270-290. In: Reis R. E., S. O. Kullander $\&$ C. J. Ferraris Jr. (Eds) Check List of the Freshwater Fishes of South America. Porto Alegre, Edipucrs, 729p.

Sato, L. S. 2003. Estudos citogenéticos e de sequiências de DNA em Trichomycteridae (Teleostei, Siluriformes), com ênfase no gênero Trichomycterus. Unpublished Master Thesis. Instituto de Biociências, Universidade Estadual Paulista. 66p.

Sato, L. R, C. Oliveira \& F. Foresti. 2004. Karyotype description of five species of Trichomycterus (Teleostei, Siluriformes, Trichomycteridae). Genetics and Molecular Biology, 27(1): 45-50.

Torres, R. A., F. Foresti \& C. Oliveira. 1998. Comparative cytogenetic studies in alopatric populations of Trichomycterus paolence Eigenmann, 1918 from Southeastern Brazil (Siluriformes, Trichomycteridae). Cytologia, 63: 107-114.

Wosiacki, W. B. 2002. Estudo das relações filogenéticas de Trichomycterinae (Teleostei, Siluriformes) com uma proposta de classificação. Unpublished Doctoral Thesis. Instituto de Biociências, Universidade de São Paulo. 324 p.

Wosiacki, W. B. \& J. C. Garavello. 2004. Five new species of Trichomycterus from the rio Iguaçu (rio Paraná Basin), southern Brazil (Siluriformes: Trichomycteridae). Ichthyological Exploration of Freshwaters, 15: 1-16.

Received July 2004 Accepted September 2004 